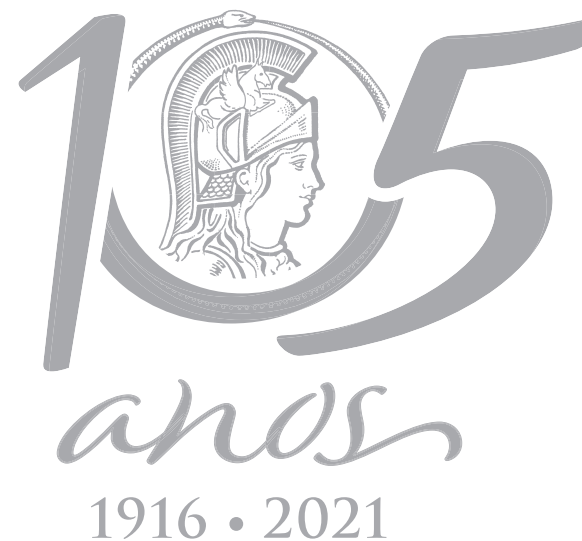

$1916 \cdot 2021$

\title{
Evaluation of Technical Feasibility of Reusing Coal Ash in Dense Asphalt Mixes by Assessing Mechanical Performance
}

\author{
BRENO BARRA, LETO MOMM, YADER GUERRERO, ALEXANDRE MIKOWSKI, \\ ESTÉFANI CLARA, MAI-LAN NGUYEN \& GARY B. HUGHES
}

\begin{abstract}
This manuscript evaluates the technical feasibility of reusing coal ash in the formulation design of dense asphalt mixes. Physicochemical and mineralogical properties of fly and bottom ash matrixes prepared with coal ash were analyzed by scanning electron microscopy (SEM), X-Ray diffraction (XRD), semi-quantitative spectrometry by X-Ray fluorescence (XRF) and surface characterization by Nitrogen $\left(\mathrm{N}_{2}\right)$ adsorption. Filler fractions under $0.075 \mathrm{~mm}$ with $6.0 \%$ in weight from an entirely gneissic aggregate gradation curve taken as reference were compared to identical mixes prepared with fly and bottom ashes individually and also to a combined sample with 3.0\% of each ash type. Tests on compaction ability with gyratory shear press, resistance to action of water and to rutting were carried out to compare mechanical performance. The results indicate that both gneissic and coal ash fillers do not form dipoles of effective electric attractions to bituminous matrixes, resulting in inert and hydrophilic behavior regarding to action of water, respectively. Despite surface and morphologic characteristics underlying the mechanical performance of gneissic fillers, coal ash matrixes have shown, in general, good technical feasibility to be used in asphalt mixes.
\end{abstract}

Key words: asphalt mixes, characterization, coal ash, mechanical performance, properties.

\section{INTRODUCTION}

Energy supplied by thermo power plants (TPP) through burning coal is a predominant source in the current world market, representing from $27 \%$ to $38 \%$ of global electricity generation (WCA 2020, BP 2019).

Statistical projections estimate that even with clean energy production being massively encouraged, coal will maintain its current global role until 2040, being overtaken slightly by natural gas and solar photovoltaic panels. The main reasons for this coal conundrum are its large global availability, more than 1 trillion tons, i.e., capable to attend the current demand for the next 130 years, and geographic distribution of the reserves, besides the low cost and price stability when compared to other fuel sources (IEA 2019).

China, United States of America and India are responsible for at least $70 \%$ of the global consumption of coal for electric energy generation (Tiwari et al. 2014). According to Mangi et al. (2019), it is estimated that the annual worldwide production of coal ash waste after combustion is around 600 million tons, of which approximately $83 \%$ comprises a fly ash fraction.

Brazil has $0.7 \%$ of world and $42 \%$ of South American coal reserves, all concentrated in the southern region. Energy generated by Brazilian TPP represents less than $5.0 \%$ of the national 
energy matrix (MME 2020, Tolmasquim 2016). However, Jorge Lacerda's Complex (JLC), located in State of Santa Catarina, taken as study case in this research, has a non-negligible average coal consumption ranging from 200 to 330 kilotons per month, generating from 84 to 138 kilotons of ashes, depending on the climate conditions for operation (Rohde 2016).

Fly ash produced in JLC has been largely repurposed by cement and concrete industries; bottom ash has no such destination yet, generating huge accumulation in the deposition basins. These conditions cause several difficulties of waste management and ongoing hazards of groundwater contamination, due to long-term environmental risk of leaching and seepage of heavy metals from the ash deposits through soil layers and into groundwater reservoirs (Clara 2020).

Several studies have explored the use of coal ashes in pavement works (Li et al. 2019, Woszuk et al. 2019, Omrani \& Modarres 2018, Le et al. 2018, 2017, Dwivedi \& Jain 2014, in order to seek solutions for the destination of this waste in large scale, usually replacing partially the crushed aggregate particles extracted from detonated massive rock of quarries with coal ash.

In the context of large-scale re-purposing TPP coal ash waste, this study aims to amplify scientific discussions and points of view on feasible mitigation of environmental impacts. Physicochemical and mineralogical properties of fly and bottom ashes are evaluated, in comparison to gneissic massive rock particles, to verify their influence on formulation design and mechanical performance of dense asphalt mixes, contributing to provide sustainable building materials for development of infrastructure services.

\section{MATERIALS AND METHODS}

\subsection{Materials}

Coal ashes produced in JLC are solid waste created by burning processes in TPP, as a result of powdered coal combustion at high temperatures into boilers, thereby producing steam which is used in electric energy generation (Aquino et al. 2017).

The existence of distinct temperature zones inside the steam boilers make the powdered coal to have, after burning, different physical, chemical, mineralogical, macro and microstructural characteristics, in the form of ashes, being usually classified in two types: fly and bottom (Leandro 2005, Usmen et al. 1983).

The aggregate gradation determined by mechanical sieving processes for both fly and bottom ashes are illustrated in Fig. 1.

\subsection{Methodology}

Physicochemical and mineralogical properties of fly and bottom ashes were analyzed under different conditions by using American Standard for Testing Materials references (ASTM 2020). Measured ash parameters were compared to those of massive gneissic rock particles, chosen to be the main granular matrix of the asphalt mix, in order to verify compatibility between both materials when forming the same aggregate gradation.

Filler particles under $0.075 \mathrm{~mm}$ were used to evaluate the pertinent properties, respecting the proportion of $6.0 \%$ in weight with regards to the aggregate gradation of the asphalt mix formulation, with specific details presented in subsection 2.2.4.

Mechanical evaluations were carried out with a dense asphalt mix formulated by using Füller-Thompson (1907) method, taking into account parameters such as compaction ability with gyratory shear press, resistance to action 


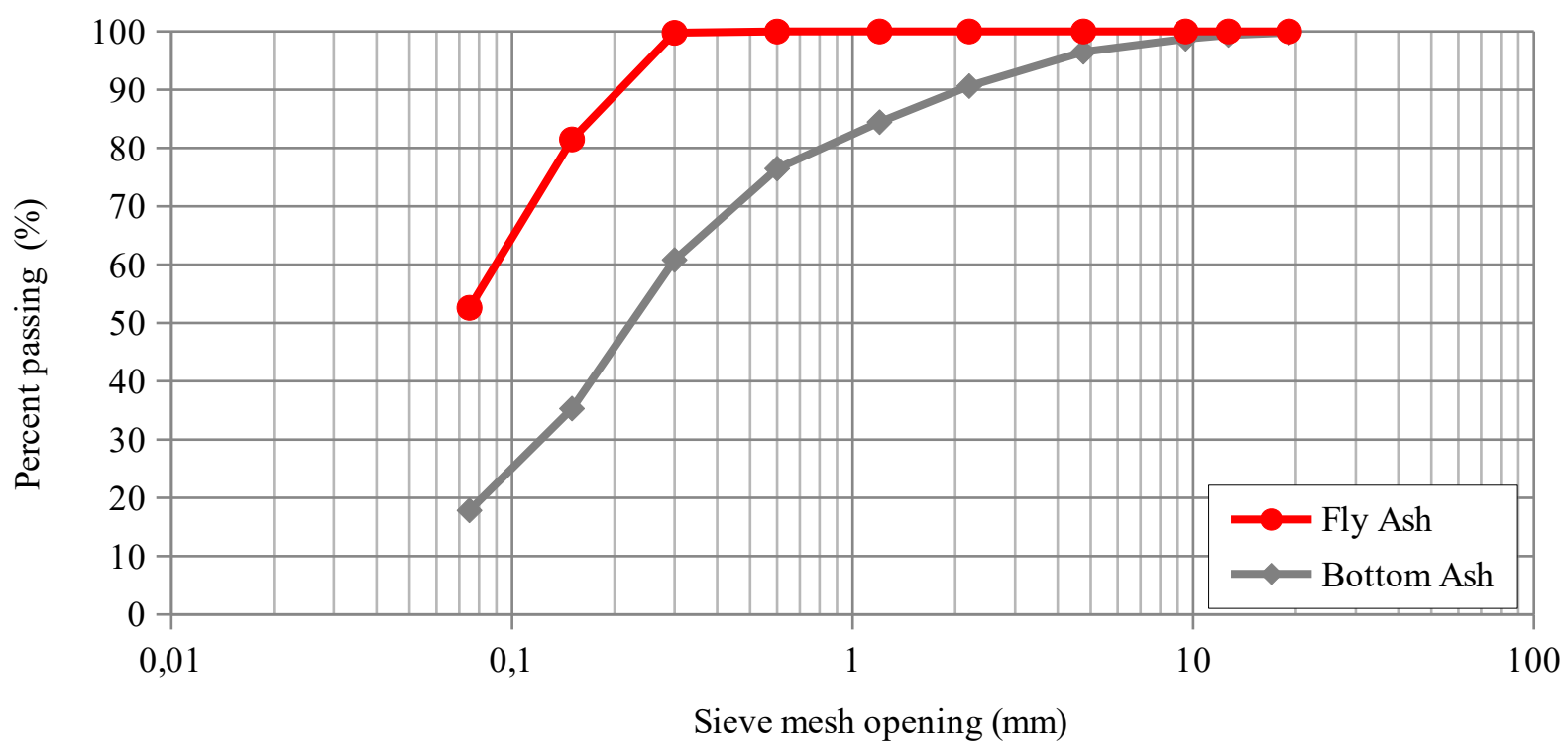

Figure 1. Aggregate gradation of fly and bottom ashes.

of water and to rutting, according to French standardized procedures (Manuel LPC 2007).

\subsubsection{Morphology}

Image capture with an optical microscope and scanning electron microscopy (SEM) procedures (ASTM E986-04 2017) were performed to evaluate the morphology of both fly and bottom ashes, in comparison to gneissic filler particles, focusing principally on micro- and macro-texture aspects using Zeiss Primotech and Zeiss EVO MA10 models, respectively.

\subsubsection{Mineralogy}

Elementary mineralogical compositions and their respective phase distributions determine the level of compatibility that particles may present with regards to good or bad chemical attraction, which is decisive to provide or not an efficient adhesion between granular-bituminous binder systems. X-Ray diffraction (XRD) tests (ASTM C1721-15 2015, Burnett 1995) were carried out with a Philips MP1880 diffractometer, considering a sweep angle of 27 and Ritveld method for mineralogical quantification of phases. Semi-quantitative energy dispersive X-Ray fluorescence spectrometry (XRF) (ASTM E1621 2013) was carried out with a Shimadzu EDX 7000 Spectrometer to probe bulk elemental composition of the matrix mixtures.

All samples were previously submitted to loss of ignition test (ASTM D7348-07 2007), in order to eliminate organic components and water from their original constitutions.

\subsubsection{Surface characteristics}

These analyses were carried out, in order to determine physical properties of the particles, specifically surface morphology, porous volume and diameter, which can be very useful to provide suitable anchorage to a bituminous binder matrix, consequently, improving the mechanical resistance of the asphalt mix. Nitrogen $\left(\mathrm{N}_{2}\right)$ adsorption was used for sample preparation (ASTM E1829-14 2014) by using a surface analyzer device from Quantachrome Instruments, model Quadrasorb-evo. 


\subsubsection{Asphalt mix formulation}

Determination of the aggregate gradation with regards the asphalt mix formulation was based on Füller-Thompson method (1907) (Eqs. 1 and 2) and designed by Barra et al. (2016), fixing characteristic parameters of the aggregate gradation curve, such as: maximum diameter, percent passing through the smallest sieve mesh opening and gradation exponent.

$\% p=a\left(\frac{d}{D}\right)$

$$
n=\frac{\log \left(\% p_{0.075 m m}\right)-\log (100)}{\log \left(\frac{0.075}{D}\right)}
$$

where ' $\% p^{\prime}$ ' is the percent passing in weight; ' $a$ ' is a constant, taken as 100; ' $d$ ' is the opening of a given sieve mesh ( $\mathrm{mm})$; ' $\mathrm{D}$ ' is the maximum diameter of the aggregate gradation curve designed $(\mathrm{mm})$, corresponding to the sieve opening mesh in which passes $100 \%$ of the particles; ' $n$ ' is the gradation exponent that indicates if the aggregate gradation is open or dense graded; and ' $\% \mathrm{p}_{0.075 \mathrm{~mm}}$ ' is the percent passing through the smallest sieve mesh opening with regards the series chosen by the designer, $0.075 \mathrm{~mm}$ in this particular case.

Values in Table I indicate that ' $D$ ' corresponds to $19.1 \mathrm{~mm}$ and ' $\% \mathrm{p}_{0.075 \mathrm{~mm}}$ ' to $6.0 \%$. Therefore, applying these values to the Eq. (2) a ' $n$ ' of 0.51 is obtained, which means a dense graded distribution, due to be comprised in the interval $0.35 \leq \mathrm{n}<0.55$ (FHWA 2006). The choice of $6.0 \%$ for ' $\% p_{0.075 m m}$ ' was based on the research conducted by Momm (1998), having concluded that dense asphalt mixes formulated with ' $\% p_{0.075 m m}$ ' from $5.0 \%$ to $7.0 \%$ presented better mechanical performance based on rutting, stiffness modulus and fatigue resistance tests, carried out on several aggregate gradations by using Füller-Thompson method.

Bituminous binder with 30/45 (0.1 mm) penetration was used to formulate the dense asphalt mixes used in this research, comprising the following contents by weight: 4.22\%, 4.54\%, $4.70 \%$ and $4.86 \%$. The temperatures adopted for mixing and compacting procedures were 155으 and $1450 \mathrm{C}$, respectively, which were determined after carrying out Brookfield viscosity tests (ASTM D4402M-15 2015).

The aggregate gradation taken as reference was entirely formed by particles from crushed massive gneissic rock (GR), which was compared to three other variations of the same percent distribution presented in Table I, but replacing $6.0 \%$ crushed rock filler fractions under $0.075 \mathrm{~mm}$ by fly ash (FA), bottom ash (BA) and an equal combination of $3.0 \%$ of both ashes (FBA) (Clara 2020). Rationale for these choices is provided in section 3.

Table I. Aggregate gradation designed (Barra et al. 2016).

\begin{tabular}{|c|c|c|}
\hline $\begin{array}{c}\text { Sieve mesh } \\
\text { opening (mm) }\end{array}$ & $\begin{array}{c}\text { Percent } \\
\text { Passing } \\
\mathbf{( \% )}\end{array}$ & $\begin{array}{c}\text { Retained } \\
\text { Percent } \\
\mathbf{( \% )}\end{array}$ \\
\hline 19.1 & 100.0 & - \\
\hline 12.7 & 81.3 & 18.7 \\
\hline 9.50 & 70.1 & 11.1 \\
\hline 4.76 & 49.4 & 20.8 \\
\hline 2.20 & 33.4 & 16.6 \\
\hline 1.20 & 24.5 & 8.8 \\
\hline 0.60 & 17.2 & 7.3 \\
\hline 0.30 & 12.1 & 5.1 \\
\hline 0.15 & 8.5 & 3.6 \\
\hline 0.075 & 6.0 & 2.5 \\
\hline- & - & 6.0 \\
\hline
\end{tabular}


The dense asphalt mix described by French methodology as Béton Bitumineux Semi-Grenus (BBSG) (Manuel LPC 2007), built as the surface layer in pavement structures, was taken as a reference to have its standardized performance parameters compared to the results of the tests described in subsections from 2.2.5 to 2.2.7.

\subsubsection{Compaction ability}

In field trials, after passing of the paver finisher machine, asphalt mixes are finished to the designed grade by pneumatic or roller compaction units. Each passing of these machines causes a gradual densification of the granular arrangement by shear effort.

Considering that compaction temperature specified in laboratory tests is replicated during field works, an asphalt mix must present a compaction ability with regards to air void percent that cannot present significant decrease during the first loading cycles. Excess voiding is indicative of strong sensitivity to fluency phenomenon, as well as a decrease below the minimum percent limit established for its standardized characteristics at the end of service, generating a fragile material in relation to support amplitude strains caused by traffic loading applications (Manuel LPC 2007).

Gyratory compaction shear press test (NF EN 12697-31 2007) provides a quantitative measure of compaction ability from a slow and isothermal process under low static compression effort. The test is performed by a shear gyratory movement applied in one the faces of a cylindrical specimen that spins its axis of symmetry (Fig. 2). The minimum height of the specimens is set to stop in $150.0 \mathrm{~mm}$ for a fixed diameter of same value, whereas the force applied must range from $10 \mathrm{kN}$ to $12 \mathrm{kN}$, resulting in a vertical strength of $0.6 \mathrm{MPa}$. Rotation angles $(\gtrsim)$ are 10 and 0.82 - in internal and external parts of the specimens, respectively.

Starting from a loose material, the air void percent is continuously calculated by Eq. (3) during the test at each turn of the axis of symmetry. The compaction ability of an asphalt mix is quantified by comparison with the average result of 3 specimens for each formulation to a given standardized percent range for a fixed number of turns defined according to its characteristics, i.e., equal or above $11 \%$ at 10 turns and from $4.0 \%$ to $9.0 \%$ after 80 turns to BBSG.

$\% v=100\left(\frac{h_{[n g]}-h_{\min }}{h_{n g}}\right)$

where '\%v' is the air void percent for a given number of turns; ' $h_{(n g)}$ ' is the height of the specimen at each complete turn; ' $h_{\min }$ ' is the height set for the specimen to reach at the end of the test, $150.0 \mathrm{~mm}$, specifically for tests performed for this research.

\subsubsection{Resistance to action of water}

Road asphalt surface layers suffer constant action of water from rainfall during their service lives and, as described in subsection 2.2.5, the asphalt mixes have air voids in their internal structure.

When water gets into these air voids, as its surface tension, i.e., molecular concentration, is stronger than the interface tension formed by aggregate-bituminous binder system contact zone, the result is a gradual removal of the coating binder from the surface of the particles, causing stripping phenomenon that triggers the asphalt mixes to drastically reduce their mechanical performance, causing formation of potholes and direct contact with non-bituminous substrates, and rapidly decreasing the bearing capacity of pavement structures (Hefer et al. 2006). 


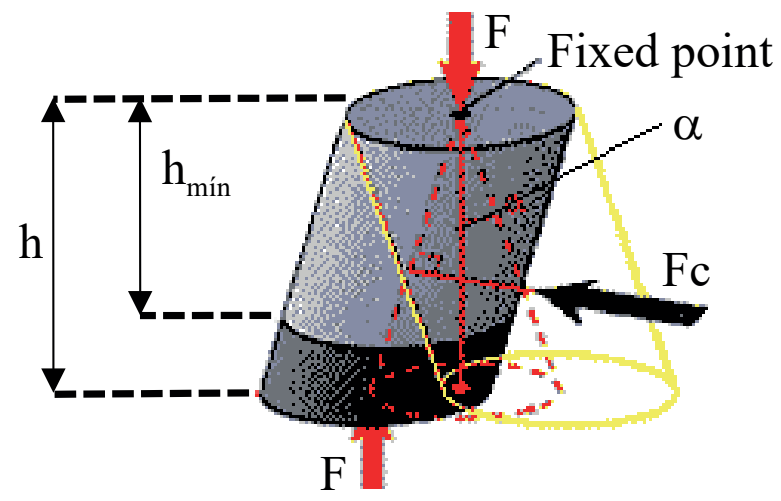

$\mathrm{h}_{\text {min }}$ : minimum height for $0 \%$ air voids

$\mathrm{h}$ : height for a given turn

$\mathrm{F}$ : axial force

Fc: shear force

$\alpha$ : inclination angle

Figure 2. Mechanical principle of the gyratory shear compaction press (Manuel LPC 2007).

Duriez test (NF EN 12697-12 2008) was carried out by applying a double-piston axial compression force of compaction with constant load of 6.0 tons during 5 minutes. A total amount of 24 specimens were molded for each formulation. After the molding process, half of the sample set was submitted to a vacuum saturation process at a constant pressure of $0.05 \mathrm{MPa}$ for 2 hours prior to submersion in water $(r)$, while the other half was subjected to a climatic chamber with air moisture controlled in $50 \% \pm 10 \%(R)$, with both procedures carried out at 18 o $C$ over 7 days.

After the environmental conditioning period, $r$ and $R$ sample sets were tested by application of axial compression force, yielding $r / R$ average values, in which a ratio $\geq 0.70$ (70\%) must be obtained for BBSG. An overview of the experimental setup for Duriez test is illustrated in Fig. 3.

\subsubsection{Rutting resistance}

For carrying out a rutting resistance test (NF EN 12697-22 2007), pairs of asphalt mix slabs were molded for each formulation tested in a pneumatic compaction machine with $180.0 \mathrm{~mm}$ (width), $500.0 \mathrm{~mm}$ (length) and $100.0 \mathrm{~mm}$ (thick). After 15 resting days to provide suitable time for the bituminous binder to anchor on the aggregate particles, each pair was in turn subjected to a machine test, whereby a single wheel axle load runs the same path in a back and forth movement at a constant cycle of $1 \mathrm{~Hz}$ and 60ㄷ (Fig. 4).

For BBSG tests, samples were subjected to sequences of 100,300, 1000,3000, 10000 and 30000 cycles (N). The results after 30000 cycles can be interpreted as follows with regards to rut depths: $\leq 5.0 \%$ is qualified as an asphalt mix capable of withstanding heavy and channeled traffic (class 3); $5.1 \%<x \leq 7.5 \%$ it is suitable for traffic where loading intensities are not very strong, but can present severe thermal gradient (class 2), i.e., 5 o $\mathrm{C}$ during the winter and 30 으 during the summer, for instance, and; > 7.5\% indicates ability to withstand traffic with low intensity and not subjected to hot temperatures or severe thermal gradients (class 1).

\section{RESULTS AND DISCUSSION}

\subsection{Morphological characteristics}

Fly and bottom ashes were observed with optical and scanning electron microscopes. Morphological characteristics are discernible in images (Fig. 5), whereby it is possible to verify a spongy aspect of the fly and bottom ashes, with presence of particles with spherical macrotexture, especially in fly ash samples. A subangular macrotexture and rough microtexture 


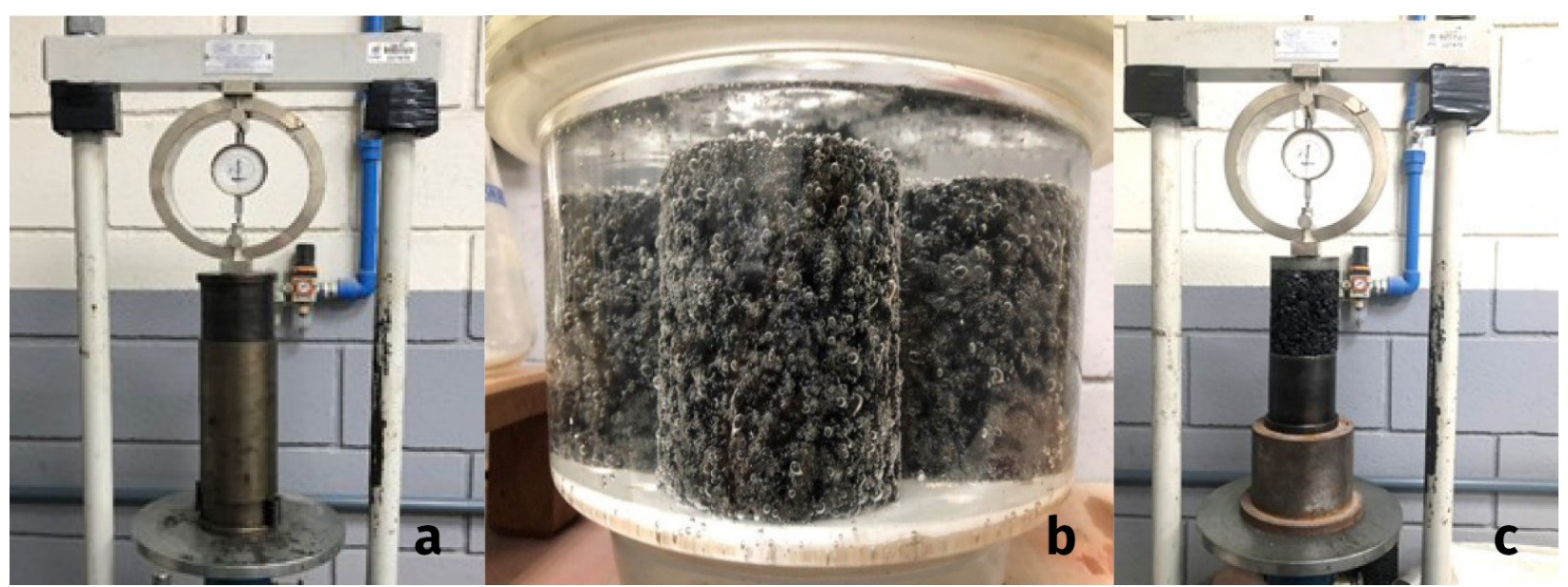

Figure 3. Overview of Duriez test: (a) double-piston compaction, (b) vacuum saturation process and, (c) rupture procedure.

is notable in both ashes, and more prominent in bottom ashes. The analogous scenario does not occur for gneissic rock particles, which provide whole samples with subangular macrotexture and rough microtexture.

According to Mainganye et al. (2013), the predominant sphericity of fly ash particles (Fig. 5a) can be attributed to covering by an amorphous layer formed during relatively sudden cooling after a combustion process.

Fused clay minerals generate vitreous spherical particles, high incidence of gaseous inclusions, i.e., forming vesicular (spongy) structures (Fig. 5b), during application of oxygengas flame. Vesicular structure indicates the critical role of temperature in the development of particle morphology in relation to the heating zone inside steam boilers; less spongy formations are due to lower temperatures in the bottom, whereas spherical forms indicate incidence of higher temperatures in the upper furnace region (Wat \& Thorne 1965), confirming the statements of Leandro (2005) and Usmen et al. (1983) cited in subsection 2.1 and the images shown in Figs. $5 a$ and 5b.

Regarding gneissic particles, because of their metamorphic origin, many sinuous planes are formed during the cooling process of rock formation, producing massive structure with rough microtexture over the faces. A predominant subangular macrotexture is due to the crushing process in the quarries, causing oriented ruptures along the cleavage angles (Mukherjee 2015).

Another important aspect concerning both ashes was remarked during this research: particles above $0.075 \mathrm{~mm}$ are friable, i.e., easily crumbled, principally those of bottom ash.

This scenario was verified after have been assessed the soundness of these particles by Sodium Sulfate attack (ASTM C88M-18 2018), in which was verified high sensitivity to fragmentation, even by pression exerted between the fingers, with a consequent reduction in the original size, checked later by sieving process, presenting loss of mass around 25\% to 30\% when compared to the range 3\% to $5 \%$ obtained from crushed gneissic rock particles. Increased friability is likely due to vesicular structures being less resistant to chemical and physical forces than massive ones.

Reduced potential friability is the primary reason for having selected both fly and bottom ash particles under $0.075 \mathrm{~mm}$ for replacing gneissic fillers in the asphalt mix formulation designed for this research, accounting for 


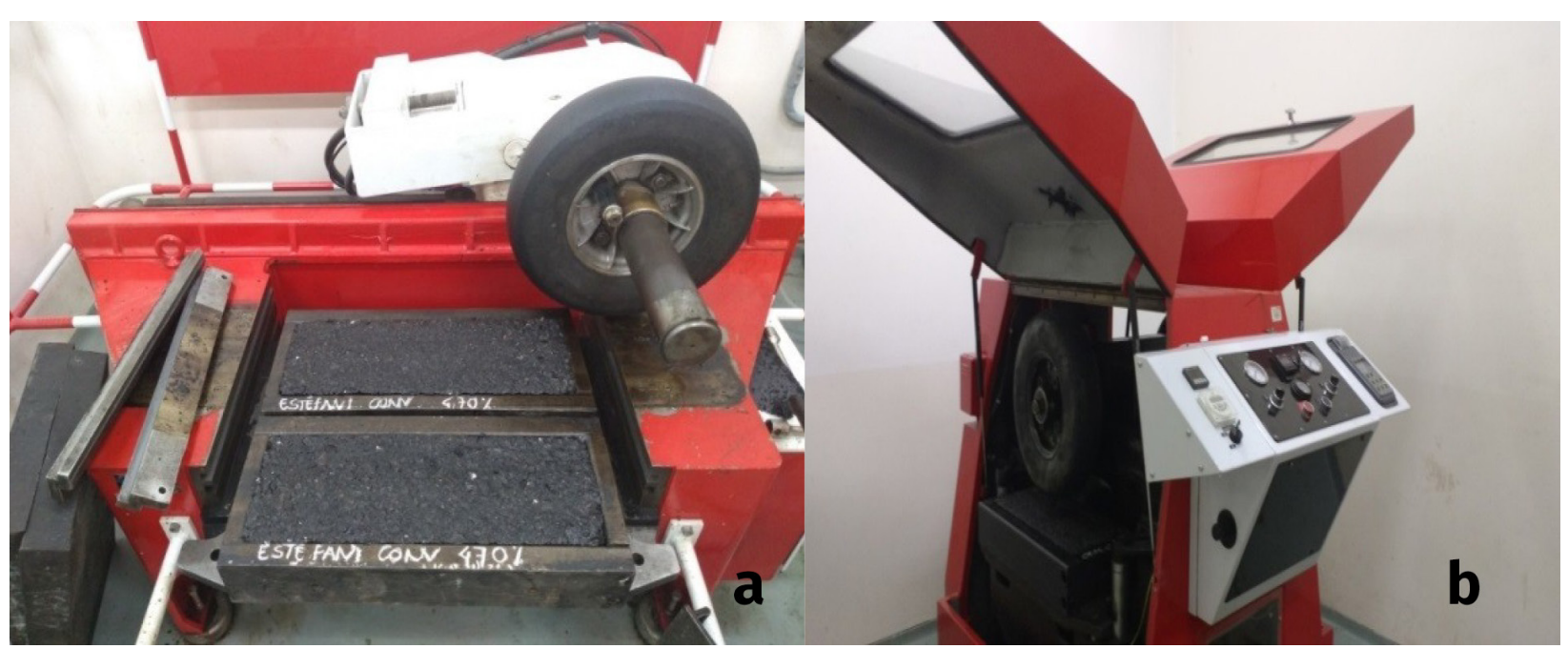

Figure 4. Rutting test during (a) slab compaction procedure and (b) the test itself.

$52.6 \%$ (fly) and $17.8 \%$ (bottom) of the aggregate gradation of these materials produced in JLC premises (Fig. 1).

\subsection{Elemental quantification by X-Ray fluorescence (XRF)}

Silicon, Aluminium and Iron are predominant elements that constitute the chemical composition of both coal ashes and of gneissic particles, representing together more than 80\% of each sample tested (Table II). The observed elemental composition reveals a strong electronegative characteristic of both materials.

The percent values obtained for loss of ignition were $1.634 \%$ (fly ash), $4.747 \%$ (bottom ash) and $2.290 \%$ (gneissic particles). Leaching and solubilization tests were carried out with the same coal ash from JLC (Oliveira et al. 2012) and with gneissic filler particles (Gonçalves 2000), both being classified as non-hazardous Type II, according to Brazilian environmental regulations (ABNT NBR 10004 2004). Confirmed laboratory results indicate that each of the tested materials are authorized for use in public works throughout Brazil.

Carnin et al. (2005) performed leaching tests in asphalt mix formulations with reuse of foundry sands containing similar chemical and mineralogical compositions in relation to coal ash and gneissic fillers of this research. As a result, it was found that the coating generated by the bituminous binder encapsulates the aggregate particles, not allowing them to be carried by water or other fluids, and thereby avoiding seepage through soil structures and direct contact to groundwaters.

Analogously, use of the same binders infers that coal ash and gneissic fillers would also become encapsulated and impervious to leaching out of trace elements within the fillers.

\subsection{Measurement of mineralogical components by X-ray diffraction (XRD)}

Diffractograms illustrated in Fig. 6 were recorded from fly and bottom ashes. The crystallized components of both ashes are equivalent, being formed essentially by Mullite, Quartz and small probable presence of Hematite. Anorite, Biotite, Albite and Quartz are the main crystalline forms observed in the gneissic massive rock particles.

The presence of Mullite in fly and bottom ash compositions likely results from thermal reactions that occur inside steam boilers during the combustion process. Quartz is 


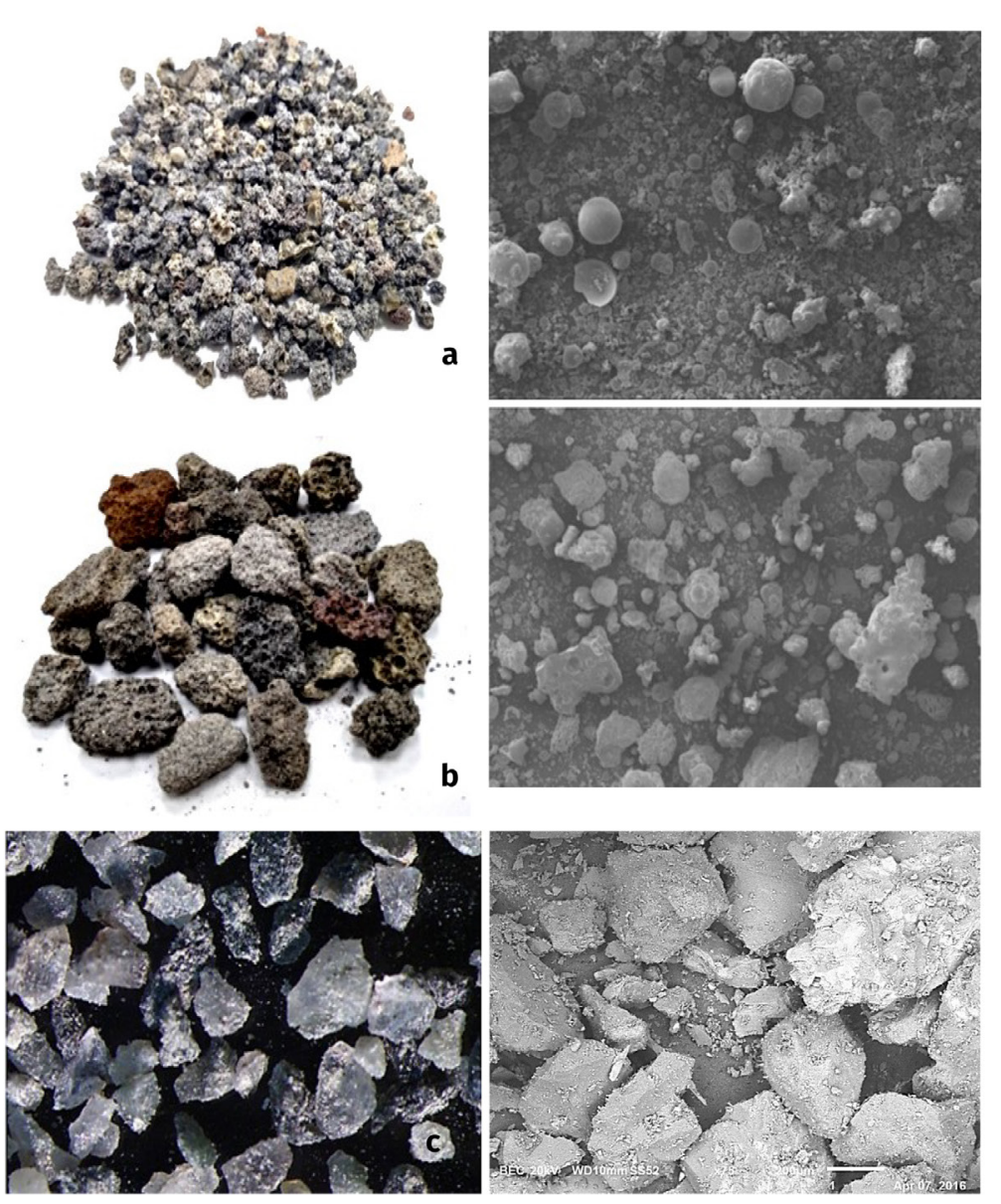

Figure 5. Images captured by optic microscope (left) and SEM amplified 300 times (right) of (a) fly ash, (b) bottom ash and (c) gneissic rock particles.

an inherent characteristic of geological coal formation, and does not fuse in the burning process at TPP. Hematite and Magnetite arise in small percentages due to Iron Sulfide oxidation typically found in burned samples (Rohde et al. 2006). For gneissic particles, the major concentration of Biotite results from a strong participation of silicates (Quartz, Mica), particularly from the iron-magnesian subgroup, containing also Potassic Feldspar (Albite - Na; Anorthite - $\mathrm{Ca} ; \mathrm{Al}_{2} \mathrm{CaD}_{16,84} \mathrm{O}_{12,42}$ ) (Mukherjee 2015).

Based on the observed mineralogical characteristics, all the materials analyzed are considered as felsic, i.e., with high acidity, due to expressive concentration of silicates. XRD results are also consistent with XRF analyses performed. Furthermore, the silicates presented in fly and bottom ashes are similar to the mineral composition of natural aggregates used in road construction, such as gneiss (Forteza et al. 2004, Xie et al. 2016).

In general, coal ashes are aluminum-silicate minerals comprised mainly of amorphous and crystalline phases (Table III), in which the first is formed by small powdered particles with pozzolanic properties, containing vitreous and spherical characteristics, and the second by geological minerals (Querol et al. 2002).

Results in Table III indicate that the amorphous phase represents more than $70 \%$ of fly and bottom ash compositions. The amorphic fraction infers that despite having predominant pozzolanic behavior, the intense electronegativity does not result in effective affinity to materials with the same chemical 
characteristics, such as materials commonly used for bituminous binders.

\subsection{Surface characteristics}

The results presented in Table IV indicate that despite both coal ashes having vesicular structure with similar average porous diameters, bottom ash samples have more porous volume concentration than fly ashes, due primarily to a smaller specific area and to lower temperatures in the lower areas of the steam boilers. The composite sample bottom/fly reveals a balance between characteristics of the individual species.

Gneissic particles present porous volume concentration similar to those in bottom ash, but almost double the average porous diameter and specific area. These aspects are attributed to a severe thermal gradient faced over geological process of environmental cooling during metamorphic rock formation (Mukherjee 2015) and to crushing works, which produce smaller particles than those precipitated inside steam boilers.

Porous characteristics of all particles helps to provide good surface physical anchorage to the bituminous binders.

\subsection{Mechanical performance of asphalt mixes}

Prior results based on French methodology (Manuel LPC 2007) considered for evaluating the asphalt mix formulations establishes a rejection criterion over all performance levels, i.e., if a single formulation does not reach a result within a given standardized limit, it cannot be forwarded to the next level, and so on.

So, as the BBSG was taken as the parametric formulation for this research (section 2.2.4), the following order of tests was carried out according to standardized protocol: compaction ability, resistance to action of water and resistance to rutting.

The asphalt mixes are designated by abbreviations, in order to simplify identification in the charts, such as: GR for the aggregate gradation formed entirely by gneissic rock particles; FA and BA for replacing 6.0\% gneissic filler fractions (< $0.075 \mathrm{~mm}$ ) by fly ash and bottom ash, respectively; and FBA for replacing $6.0 \%$ gneissic filler fractions $(<0.075 \mathrm{~mm})$ by an equal combination of $3.0 \%$ of both fly and bottom ashes.

\subsubsection{Compaction ability}

Only GR formulations were all measured above the standardized thresholds (Table V; Fig. 7), a result of less sensitivity to the first loading cycles (10 turns) and suitable conformity of the granular arrangement at the end of the test procedures after 80 turns. Subangular macrotexture and rough microtexture of the gneissic particles (Fig. 5c) are directly responsible for superior performance, due to formation of effective friction angles during the accommodation of the particles, which provide shear resistance capable of withstanding the mechanical forces.

In all cases, the air void percent decreases with the increase of asphalt binder content, due not only to the progressive contraction of empty spaces, but also due to generation of more lubrication of the particles, reducing their shear resistance and, consequently, the compaction ability.

BA formulations presented air void contents close to those of GR, especially for the smallest bituminous binder contents (4.22\% and $4.54 \%$ ), which is attributed to major participation of subangular and rough particles (Fig. 5b) when compared to FA (Fig. 5a).

However, the presence of spherical and smooth particles, even with small concentration 
Table II. Chemical composition of the coal ashes and gneissic particles.

\begin{tabular}{|c|c|c|c|c|}
\hline Element & Symbol & $\begin{array}{l}\text { Fly ash } \\
\text { (\%) }\end{array}$ & Bottom ash (\%) & Gneissic particles (\%) \\
\hline Silicon & $\mathrm{SiO}_{2}$ & 60.258 & 58.911 & 58.100 \\
\hline Aluminium & $\mathrm{Al}_{2} \mathrm{O}_{3}$ & 19.865 & 19.624 & 13.400 \\
\hline Iron & $\mathrm{Fe}_{2} \mathrm{O}_{3}$ & 7.214 & 6.999 & 9.200 \\
\hline Potassium & $\mathrm{K}_{2} \mathrm{O}$ & 4.600 & 4.298 & 1.800 \\
\hline Calcium & $\mathrm{CaO}$ & 2.874 & 1.785 & 6.300 \\
\hline Titanium & $\mathrm{TiO}_{2}$ & 1.603 & 1.539 & 0.800 \\
\hline Sulphur & $\mathrm{SO}_{3}$ & 0.806 & 0.609 & 0.100 \\
\hline Zirconium & $\mathrm{ZrO}_{2}$ & 0.102 & 0.217 & $<0.100$ \\
\hline Vanadium & $\mathrm{V}_{2} \mathrm{O}_{5}$ & 0.089 & 0.126 & - \\
\hline Chromium & $\mathrm{Cr}_{2} \mathrm{O}_{3}$ & 0.077 & 0.086 & $<0.100$ \\
\hline Zinc & $\mathrm{ZnO}$ & 0.073 & 0.044 & - \\
\hline Manganese & $\mathrm{MnO}$ & 0.040 & 0.041 & 0.200 \\
\hline Rubidium & $\mathrm{Rb}_{2} \mathrm{O}$ & 0.028 & 0.035 & - \\
\hline Strontium & SrO & 0.027 & 0.028 & 0.100 \\
\hline Yttrium & $\mathrm{Y}_{2} \mathrm{O}_{3}$ & 0.020 & 0.027 & - \\
\hline Lead & $\mathrm{PbO}$ & 0.017 & 0.008 & - \\
\hline Sodium & $\mathrm{NaO}_{2}$ & 0.673 & 0.018 & 3.300 \\
\hline Chlorine & $\mathrm{Cl}$ & - & - & 0.100 \\
\hline Phosphorus & $\mathrm{P}_{2} \mathrm{O}_{5}$ & - & - & 0.200 \\
\hline Magnesium & MgO & - & - & 4.200 \\
\hline Loss of ingnition & - & 1.634 & 4.747 & 2.290 \\
\hline
\end{tabular}

Table III. Phases of coal ash mineralogical compositions.

\begin{tabular}{|c|c|c|c|}
\hline \multirow{2}{*}{ Phase } & Mineral & $\begin{array}{c}\text { Fly Ash } \\
\text { (\% in weight) }\end{array}$ & $\begin{array}{c}\text { Bottom Ash } \\
\text { (\% in weight) }\end{array}$ \\
\hline \multirow{2}{*}{ Amorphous } & - & 74 & 75 \\
\hline \multirow{2}{*}{ Crystalline } & Quartz & 9 & 12 \\
\cline { 2 - 4 } & Hematite (Fly) / & 1 & 2 \\
\cline { 2 - 4 } & Magnetite (Bottom) & 16 & 11 \\
\hline
\end{tabular}


Table IV. Surface characteristics of the coal ashes and gneissic particles.

\begin{tabular}{|c|c|c|c|}
\hline Sample & $\begin{array}{c}\text { Specific area } \\
\left(\mathrm{m}^{2} / \mathrm{g}\right)\end{array}$ & Porous volume $\left(\mathrm{cm}^{3} / \mathrm{g}\right)$ & Average porous diameter $(\AA)$ \\
\hline Bottom ash & 1.454 & 0.013950 & 88.44 \\
\hline Fly ash & 6.311 & 0.003170 & 87.24 \\
\hline Bottom/fly & 3.933 & 0.009819 & 99.84 \\
\hline Gneissic particles & 3.052 & 0.012850 & 168.4 \\
\hline
\end{tabular}
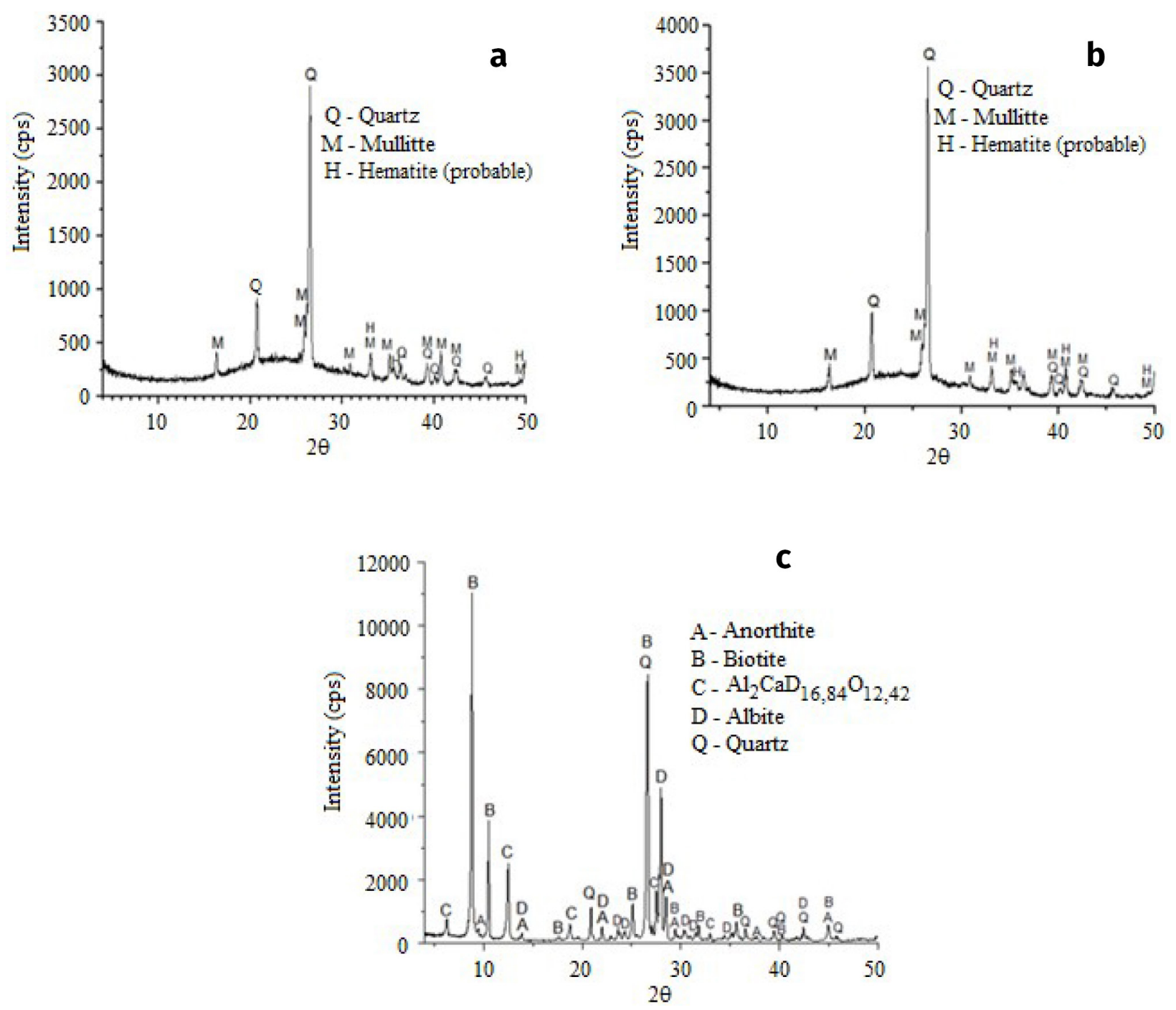

Figure 6. Diffractograms of (a) fly ash, (b) bottom ash and (c) gneissic particles.

in BA samples, contributes to reduce the shear resistance and air void percent during the first loading cycles and for the highest bituminous binder contents (4.70\%). Air void compression is stabilized towards to the end of the compaction process at 80 turns, but sometimes not enough to eliminate a given formulation, as occurred with a binder content of $4.86 \%$.

The same reasoning can be applicable to FA, but in the opposite sense, with predominant 
Table V. Air void content of the asphalt mixes in comparison to standardized thresholds.

\begin{tabular}{|c|c|c|c|}
\hline \multirow{5}{*}{ Asphalt mix } & \multirow{5}{*}{$\begin{array}{l}\text { Binder content } \\
\text { (\%) }\end{array}$} & \multicolumn{2}{|c|}{ Number of turns } \\
\hline & & 10 & 80 \\
\hline & & Air Void (V) & \\
\hline & & \multirow{2}{*}{$V_{\min } \geq 11 \%$} & $V_{\min } \geq 4.0 \%$ \\
\hline & & & $V_{\text {max }} \leq 9.0 \%$ \\
\hline \multirow{4}{*}{ GR } & 4.22 & 15.90 & 8.40 \\
\hline & 4.54 & 14.00 & 6.50 \\
\hline & 4.70 & 13.05 & 5.20 \\
\hline & 4.86 & 12.80 & 4.10 \\
\hline \multirow{4}{*}{ BA } & 4.22 & 14.45 & 8.35 \\
\hline & 4.54 & 12.95 & 6.45 \\
\hline & 4.70 & 11.00 & 4.10 \\
\hline & 4.86 & 11.00 & 3.93 \\
\hline \multirow{2}{*}{ FA } & 4.22 & 11.00 & 4.30 \\
\hline & 4.54 & 8.45 & 3.30 \\
\hline \multirow{3}{*}{ FBA } & 4.22 & 12.10 & 4.90 \\
\hline & 4.54 & 11.85 & 4.25 \\
\hline & 4.70 & 9.70 & 1.75 \\
\hline
\end{tabular}

presence of spherical and smooth particles, where only a single formulation FA 4.22\% met standardized thresholds. For FBA, an intermediary behavior was observed in relation to $B A$ and to FA, with better compaction ability than FA, apparently due to insertion of BA particles, culminating with formulations FBA $4.22 \%$ and $4.54 \%$ meeting standardized thresholds.

\subsubsection{Resistance to action of water}

Experimental results highlight the strong electrical repellence of chemical elements from granular and bituminous binder matrixes, which produces a weak interface tension that is not capable of resisting deleterious attacks of water, leading to stripping of the binder coating as indicated in Fig. 8.

The origin of stripping is likely due to repellence caused by the electronegative characteristic of the minerals in both matrixes, caused principally by predominant joint presence (> $80 \%$ ) of Silicon, Aluminium and Iron for aggregate particles, as presented in Table II, whereas the bituminous binder used in this research is formed by more than $80 \%$ Carbon (Leite \& Menezes 2003). In addition, the prominent concentration of amorphous phase (> 70\%) in both fly and bottom ash samples, as presented in Table III, has decisive influence on the non-formation of a strong dipolar attraction to the Carbon atoms in the binder. 


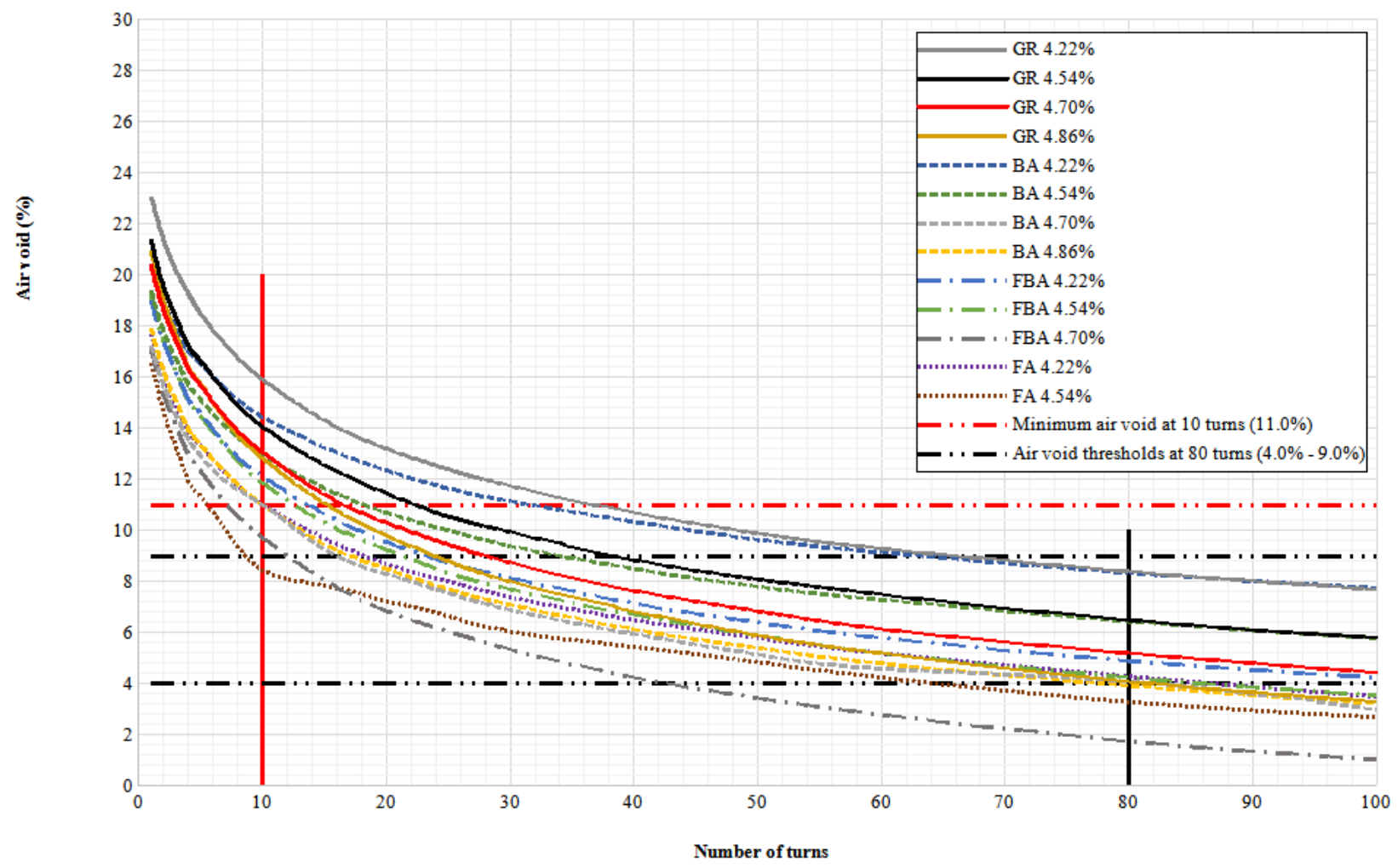

Figure 7. Evolution of the compaction ability of asphalt mixes.

To solve this problem, chemical additives must be used to modify the bituminous binder original matrix, and limestone or hydrated lime added to aggregate gradation, in order to input electropositive elements in the formulation to generate dipolar attraction to the Carbon atoms in the binder. However, none of these solutions were adopted during this research, in order to avoid influencing the true behavior of the materials.

Stripping of the asphalt binder significantly reduces the mechanical resistance of asphalt mixes, which can result in losses near the maximum acceptable standardized threshold of 30\% (Fig. 9).

The experimental values of $\mathrm{r} / \mathrm{R}$ ratio confirm the decisive role of particle morphology in the mechanical resistance of asphalt mixes, as described in section 3.5.1, particularly considering that formulation GR presented the smallest losses when compared to the others. In the same sense, observed results also verified that BA overcomes FA, which is less resistant than FBA.

It is important to remark that, in general, better $r / R$ ratios were obtained as the asphalt binder content increased for all formulations. It follows that the smallest contributor is the air void volume for a given specimen, making it more difficult for the water to penetrate and lodge in the interstitial structure of the material, thus, reducing the effective deleterious action of water at the interface of granular-asphalt binder system.

However, it should also be noted that the increase of bituminous binder content reduces the shear resistance of the asphalt mixes, as demonstrated in section 3.5.1.

\subsubsection{Rutting resistance}




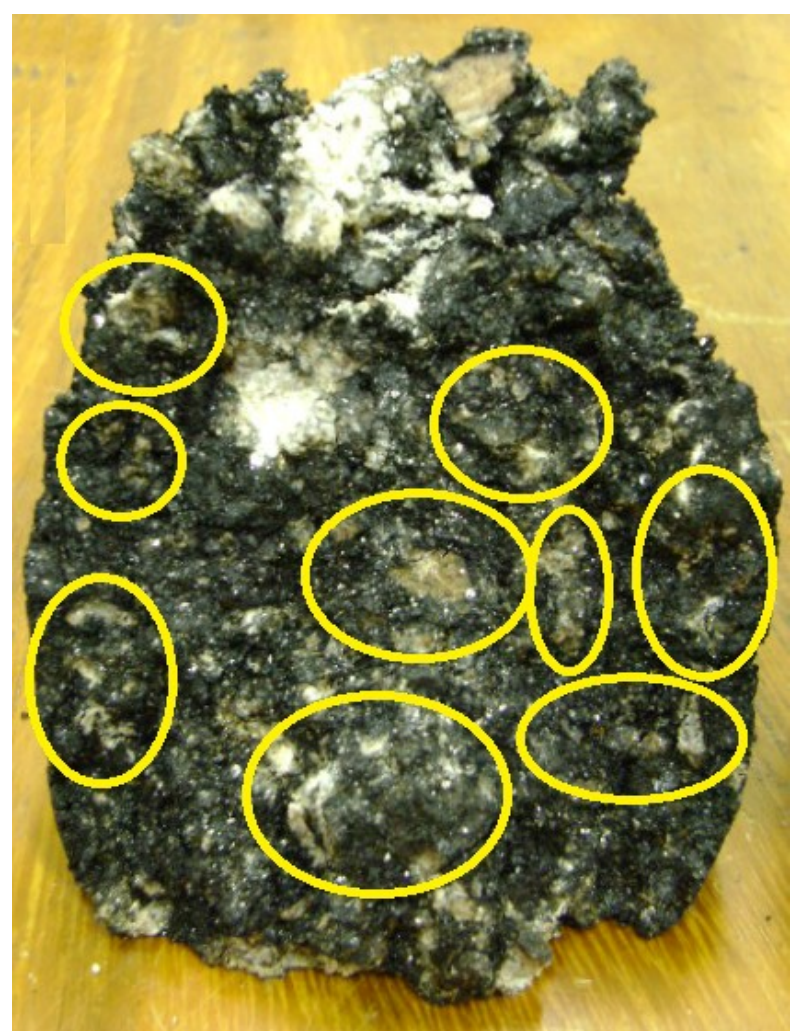

Figure 8. Removal of the asphalt binder coating due to deleterious action of water.

All asphalt formulations presented rut depths below $5.0 \%$ after 30000 cycles, except BA with $4.70 \%$ of asphalt binder content in weight, which was measured at $7.01 \%$ (Fig. 10). The majority of tested asphalt mixes conform to class 3, i.e., the noblest for BBSG per standardized thresholds, whereas BA $4.70 \%$ conforms to class 2.

Under conditions of similar bituminous binder content and taking into account the morphological aspects of granular particles in the various asphalt mixes, it is evident that formulation GR was assessed as possessing traits consistent with the trends indicated in subsections 3.5 .1 and 3.5.2, i.e., the best mechanical performance in general while FA presented the worst result. BA and FBA formulations reached similar rut depths after 30000 loading cycles, despite the latter having demonstrated less resistance to shear forces along the rutting evolution curves, due to higher presence of spherical and smooth particles provided by FA, consistent with the results of compaction ability tests.

A lubricant effect was also observed for all formulations relating to rut depth increase, as verified by compaction ability tests as a reduction of air void percent and shear resistance.

Rutting resistance also appears to be influenced by specific area, porosity and size of the filler particles, an observation that is consistent with the findings of Muniandy et al. (2012).

Data presented in Table IV and in Fig. 10 indicate the asphalt mixes that presented filler fractions with smaller specific areas and bigger porous volume achieved the best rutting results, providing greater resistance to loading cycles and better anchorage of the bituminous binder to the granular surface, respectively.

The only exception to the general relationship was observed for the gneissic filler particles (GR), because despite possessing larger specific area than BA, some characteristics such as predominant subangular macrotexture and rough microtexture, and including a larger average porous diameter, contribute to superior results than the other formulations.

The conservative design criterion regarding the use of $6.0 \%$ filler particles under $0.075 \mathrm{~mm}$ was also associated with superior results, due to reduced influence of spherical and smooth granulars in the aggregate gradation arrangement, particularly those from coal ash fractions. In general, a robust specification of less than $10 \%$ filler particles in asphalt mix aggregate gradation design has been confirmed by numerous studies (Hamidi \& Motamed 2019, Zulkati et al. 2012, Momm 1998). Based on experimental observations and assessment of the physicochemical characteristics of the JLC coal ashes, it is evident that inferior results would 


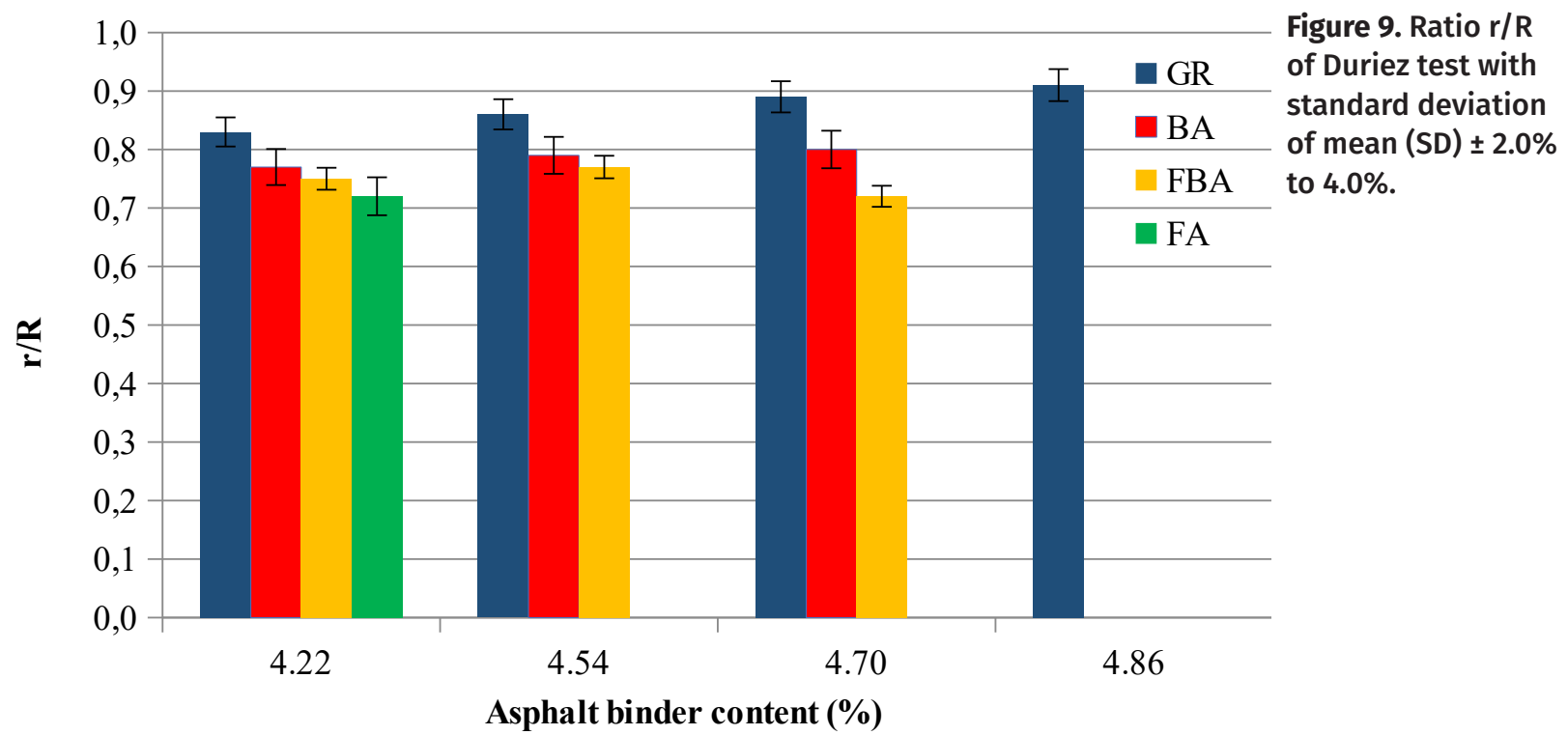

likely be obtained if higher filler concentrations had been adopted.

\section{CONCLUSIONS}

The physicochemical properties of coal wastes from thermo power plant (TPP) fly and bottom ashes were analyzed in comparison to crushed gneissic massive rock particles, in the context of filler material for asphalt mix used in infrastructure design. Experimental results were analyzed to determine relationships between physicochemical properties and the mechanical performance of dense asphalt mix formulations using coal ashes and gneissic particles as filler fractions. The following conclusions can be drawn from the experimental campaign:

- Based on the XRF analyses presented in this study, and results from associated studies (Oliveira et al. 2012, Carnin et al. 2005, Gonçalves 2000), fly and bottom ashes, as well as the gneissic particles, are non-hazardous materials and in conformity with Brazilian environmental regulations. Additionally, more than $80 \%$ of the mineral composition consists of
$\mathrm{SiO}_{2}, \mathrm{Al}_{2} \mathrm{O}_{3}$ and $\mathrm{Fe}_{2} \mathrm{O}_{3}$, which implies a strong electronegative characteristic;

- Mineralogical characterization (XRD) revealed that fly and bottom ashes are predominantly amorphous, and the typical crystalline phase is formed by $\mathrm{SiO}_{2}$ in mineral forms of Quartz, Mullite, Hematite and Magnetite, being the primary constituent of coal ashes;

- The characteristic influence of electronegative elements makes both gneissic and coal ash fillers not receptive to formation of dipole attractions to bituminous binders, allied to the inert behavior of the ashes provided by the predominant amorphous phase, promoting bad chemical bonding and stripping phenomenon, as confirmed by the Duriez tests. However, these issues can be easily mitigated in designing mixtures with suitable electropositive chemical additives or derivatives of $\mathrm{CaO}$ in the formulation, such as limestone or hydrated lime;

- Compaction ability and rutting tests demonstrated that despite surface texture and morphological characteristics 


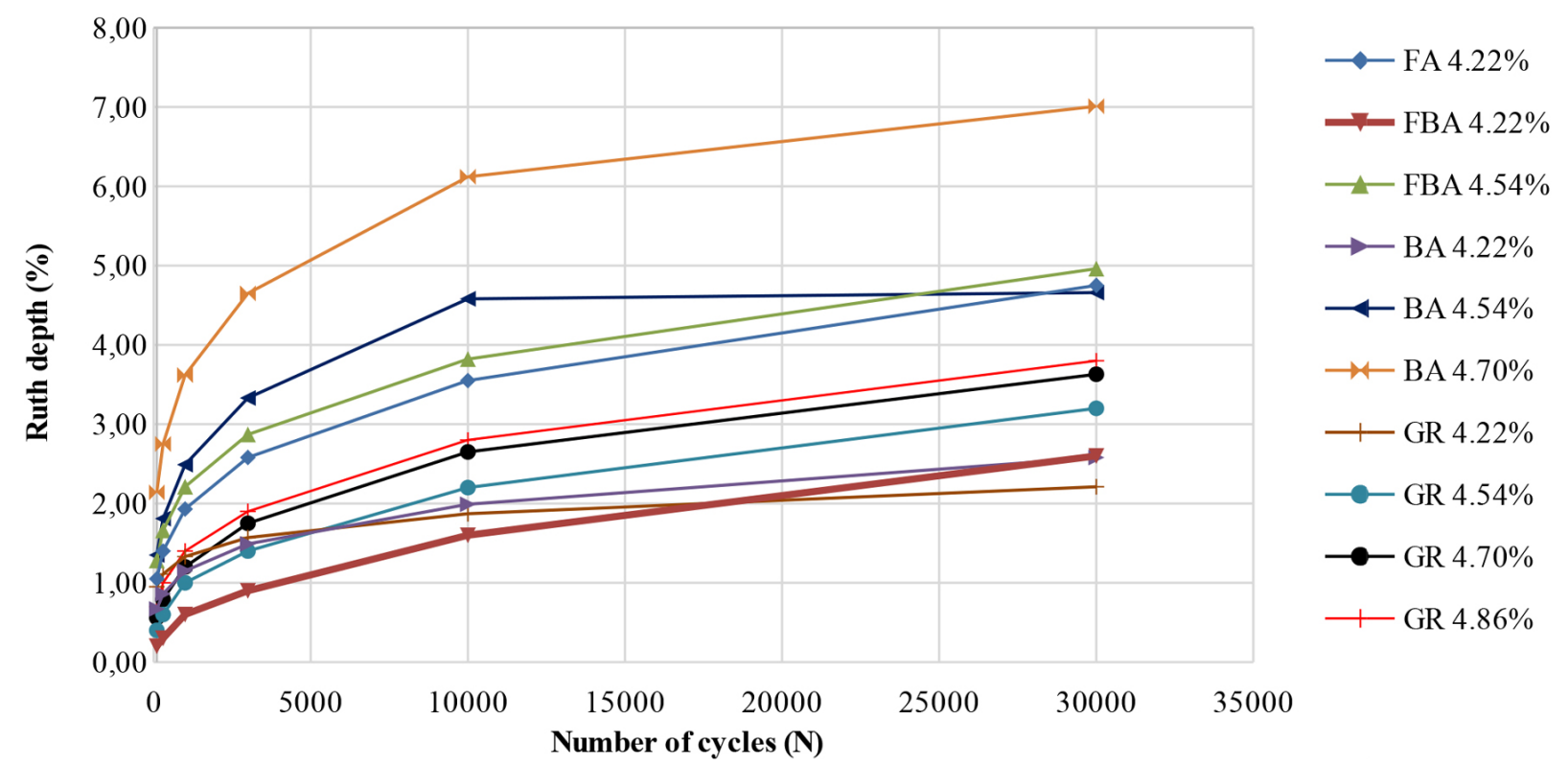

Figure 10. Rutting evolution of the asphalt mixes.

being more favorable to mechanical performance of gneissic fillers (GR), the coal ashes have presented, in general, very interesting potential for use as raw material with regards to asphalt mix formulation design, especially the bottom ash (BA) and fly/bottom ash combination (FBA), highlighting the first, while fly ash (FA) solely did not present good mechanical performance;

- $6.0 \%$ of filler particles in aggregate gradation curve have demonstrated to be suitable for the major part of the formulations for mix properties concerning mechanical performance. Otherwise, the assumed risks of failure are very high if a higher percent is adopted, due to variability of their characteristics, principally morphology.

- Based on these findings, the technical feasibility of reusing coal ashes in asphalt mix formulations has been demonstrated, with coal ash being a direct and safe contribution to preserve the environment, mitigating the impact derived from thermal power plant activities while providing sustainable building materials to develop infrastructure services.

\section{Acknowledgments}

We would like to express our sincere appreciation to Petrobrás S.A. for financing this research via Cooperation Agreement Term 0050.0075479.12.9 / Project no-4600373381, and to Polytechnical School of the University of São Paulo (USP) for allowing the authors to use their laboratory equipment and premises.

\section{REFERENCES}

ABNT NBR 10004. 2004. Resíduos sólidos - classificação. Associação Brasileira de Normas Técnicas, Norma Brasileira. Rio de Janeiro, Brazil.

AQUINO TF, ESTEVAM ST, CORRÊA GR, MARQUES CRM, MELO AR, MARCELLO RR, PIRES M, HAMMERSCHMITT M \& RIELLA HG. 2017. Síntese de zeólitas do tipo $X$ a partir de cinzas volantes e de fundo de carvão mineral. In: Proceedings of the $V$ Congresso Brasileiro de Carvão Mineral. Criciúma, SC, Brazil.

ASTM. 2020. Annual Book of ASTM Standards - Complete Set, American Society for Testing and Materials. West Conshohocken. PA, USA. 
ASTM C88M-18. 2018. Standard Test Method for Soundness of Aggregates by Use of Sodium Sulfate or Magnesium Sulfate, American Society for Testing and Materials. West Conshohocken. PA, USA.

ASTM C1721-15. 2015. Standard Guide for Petrographic Examination of Dimension Stone, American Society for Testing and Materials. West Conshohocken. PA, USA.

ASTM D7348-07. 2007. Standard Test Methods for Loss on Ignition (LOI) of Solid Combustion Residues, American Society for Testing and Materials. West Conshohocken. PA, USA.

ASTM D4402M-15. 2015. Standard Test Method for Viscosity Determination of Asphalt at Elevated Temperatures Using a Rotational Viscometer, American Society for Testing and Materials. West Conshohocken. PA, USA.

ASTM E986-04. 2017. Standard Practice for Scanning Electron Microscope Beam Size Characterization, American Society for Testing and Materials. West Conshohocken. PA, USA.

ASTM E1621-13. 2013. Standard Guide for Elemental Analysis by Wavelength Dispersive X-Ray Fluorescence Spectrometry, American Society for Testing and Materials. West Conshohocken. PA, USA.

ASTM E1829-14. 2014. Standard Guide for Handling Specimens Prior to Surface Analysis, American Society for Testing and Materials. West Conshohocken. PA, USA.

BARRA B, MOMM L, GUERRERO Y, AL-QURESHI H, MIKOWSKI A \& MICHELS R. 2016. Temperature implications on rheologicalmechanical behavior and design of high modulus dense asphalt mix. Constr Build Mater 125: 135-144. https://doi. org/10.1016/j.conbuildmat.2016.08.037.

BP. 2019. BP Energy Outlook. Available at https://www. bp.com/content/dam/bp/business- sites/en/global/ corporate/pdfs/energy-economics/energy-outlook/bpenergy-outlook-2019.pdf.

BURNETT A. 1995. A Quantitative X-Ray Diffraction Technique for Analyzing Sedimentary Rocks and Soils. J Test Eval 23(2): 111-118. https://doi.org/10.1520/JTE10902J.

CARNIN RLP, MATOSSO FILHO NP \& MOMM L. 2005. Reaproveitamento do Resíduo Areia Verde de Fundição em Misturas Asfálticas. In: Proceedings of the 12음 Congresso de Fundição. 316-325. São Paulo, Brasil.

CLARA E. 2020. Avaliação de misturas asfálticas densas com a incorporação de cinza de carvão mineral. Master's Dissertation. Federal University of Santa Catarina (UFSC), 164 p. Joinville, Brasil.
DWIVEDI A \& JAIN MK. 2014. Fly ash - waste management and overview: a review. Recent Res Sci Technol 6(1): 3035. Available online: http://recent-science.com/.

FHWA. 2006. Hot Mix Asphalt Concrete. The Handbook of Highway Engineering. Taylor \& Francis Group. LLC, p. 7-2. 7-7. 7-22. 7-23. and 7-24. Boca Raton. Florida, USA.

FORTEZA R, FAR M, SEGUÍ C \& CERDÁ V. 2004. Characterization of bottom ash in municipal solid waste incinerators for its use in road base. J Waste Manag 24(9): 899-909. https://doi.org/10.1016/j.wasman.2004.07.004.

FÜLLER WB \& THOMPSON SE. 1907. The Laws of Proportioning Concrete. J Transp Eng-ASCE (59): 67-143.

GONÇALVES JP. 2000. Utilização do resíduo de corte de granito (RCG) como adição para produção de concretos. Bachelor's Degree Monography. Federal University of Rio Grande do Sul (UFRGS), 120 p. Porto Alegre, Brazil.

HAMIDI A \& MOTAMED A. 2019. The effect of filler type and content on rutting resistance of asphaltic materials. Int J Pavement Res Technol 12: 249-258. https://doi. org/10.1007/s42947-019-0031-2.

HEFER A, BASHIN A \& LITTLE D. 2006. Bitumen Surface Energy Characterization Using a Contact Angle Approach. J Mater Civ Eng 18(6). https://doi.org/10.1061/ (ASCE)0899-1561(2006)18:6(759).

IEA. 2019. World Energy Outlook. International Energy Agency. Flagship report. Available online: https://www. iea.org/reports/world-energy-outlook-2019.

LE NH, ABRIAK NE, BINETRUy C \& BENZERZOUR M. 2017. Mechanical behavior of municipal solid waste incinerator bottom ash: Results from triaxial tests. J Waste Manag 65: 37-46. https://doi.org/10.1016/j.wasman.2017.03.045.

LE NH, RAZAKAMANANTSOA A, NGUYEN M-L, PHAN VT, DAO P-L \& NGUYEN DH. 2018. Evaluation of physicochemical and hydromechanical properties of MSWI bottom ash for road construction. J Waste Manag 80: 168-174. https:// doi.org/10.1016/j.wasman.2018.09.007.

LEANDRO RP. 2005. Estudo laboratorial acerca da possibilidade de aproveitamento da cinza pesada de termelétrica em bases e sub-bases de pavimentos flexiveis. Master's Dissertation in Civil Engineering, 170 p. University of São Paulo (USP). São Paulo, Brasil.

LEITE LFM \& MENEZES SMC. 2003. Efeito da composição química dos ligantes na resistência ao descolamento de misturas asfálticas. In: Proceedings of the XVII Congresso Nacional de Pesquisa em Transporte da ANPET. Rio de Janeiro, RJ, Brasil. 
LI J, XIAO F, ZHANG L \& AMIRKHANIAN SN. 2019. Life cycle assessment and life cycle cost analysis of recycled solid waste materials in highway pavement: a review. J Clean Prod 233: 1182-1206. https://doi.org/10.1016/j. jclepro.2019.06.061.

MAINGANYE D, OJUMU TV \& PETRIK L. 2013. Synthesis of zeolites Na-P1 from South Africa coal fly ash: effect of impeller design and agitation. Materials (Basel) 6(5): 2074-2089. https://doi.org/10.3390/ma6052074.

MANGI SA, IBRAHIM MHW, JAMALUDDIN N, ARSHAD MF \& MUDJANARKO SW. 2019. Recycling of Coal Ash in Concrete as a Partial Cementitious Resource. MDPI Journals and ACS Style 8: 99. https://doi.org/10.3390/resources8020099.

MANUEL LPC. 2007. Manuel LPC d'aide à la formulation des enrobés. Groupe de Travail RST "Formulation des enrobés". Laboratoire Central des Ponts et Chaussées, 199 p. Paris, France.

MME. 2020. Boletim Mensal de Monitoramento do Sistema Elétrico Brasileiro. Ministério de Minas e Energia, 39 p. Brasília, DF, Brasil. http://www.mme.gov.br.

MOMM L. 1998. Estudo dos efeitos da granulometria sobre a macrotextura superficial do concreto asfáltico e seu comportamento mecânico. PhD Thesis. University of São Paulo (USP), São Paulo, 289 p.

MUKHERJEE S. 2015. Atlas of Structural Geology. Ed. Elsevier Ltd., 200 p. https://doi.org/10.1016/C2013-0-09971-9.

MUNIANDY R, ABURKABA E, YUNUS R, HAMID H \& SALIHUDIN H. 2012. Influence of mineral filler particle size and type on rheological and performance properties of SMA asphaltfiller mastics. Asian J Appl Sci 5(8): 522-537. https://doi. org/10.3923/ajaps.2012.522.537.

NF EN 12697-31. 2007. Mélanges bitumineux - Méthodes d'essai - Partie 31: Confection d'éprouvettes à la presse à compactage giratoire (PCG). Norme Française, European Normalization. Association Française de Normalisation. Paris, France.

NF EN 12697-12. 2008. Mélanges bitumineux - Méthodes d'essai - Partie 12: Détermination de la sensibilité à l'eau des éprouvettes bitumineuses. Norme Française, European Normalization. Association Française de Normalisation. Paris, France.

NF EN 12697-22. 2007. Mélanges bitumineux - Méthodes d'essai - Partie 22: Essai d'orniérage. Association Française de Normalisation. Norme Française, European Normalization. Paris, France. Brazil

OLIVEIRA MLS, WARD CR, FRENCH D, HOWER JC, QUEROL X \& SILVA OLIVEIRA LF. 2012. Mineralogy and leaching characteristics of beneficiated coal products from Santa Catarina, Brazil.
Int J Coal Geol 94(1): 314-325. https://doi.org/10.1016/j. coal.2011.10.004.

OMRANI MA \& MODARRES A. 2018. Emulsified cold recycled mixtures using cement kiln dust and coal waste ashmechanical-environmental impacts. J Clean Prod 199: 101-111. https://doi.org/10.1016/j.jclepro.2018.07.155.

QUEROL X, MORENO N, UMANÃ JC, ALASTUEY A, HERNÁNDEZ E, LÓPEZ-SOLER A \& PLANA F. 2002. Synthesis of zeolites from coal fly ash: an overview. Int J Coal Geol 50(1-4): 413-423. https://doi.org/10.1016/S0166-5162(02)00124-6.

ROHDE GM. 2016. Quantificação de cinzas de carvão fóssil produzidas no Brasil. Boletim Técnico no 36. Porto Alegre, RS, Brasil.

ROHDE GM, ZWONOK O, CHIEFS F \& SILVA NIW. 2006. Cinzas de carvão fóssil no Brasil - aspectos técnicos e ambientais. CIENTEC. Vol. 1. Porto Alegre, RS, Brasil.

TIWARI M, SAHU K, BHANGARE C \& AMJAL Y. 2014. Elemental characterization of coal, fly ash, and bottom ash using an energy dispersive $x$-ray fluorescence technique. Appl Radiat Isot 90: 53-57. https://doi.org/10.1016/j. apradiso.2014.03.002.

TOLMASQUIM MT. 2016. Energia Termelétrica: Gás Natural, Biomassa, Carvão Nuclear. Empresa de Pesquisa Energética (EPE). Rio de Janeiro, Brasil. http://www.epe. gov.br/.

USMEN MA, HEAD WJ \& MOULTON LK. 1983. Use of coalassociated waste in low-volume roads. Transp Res Rec (898): 268-277.

WATT JD \& THORNE DJ. 1965. The composition and pozolanic properties of pulverized fuel ashes. Part 1: Composition of fly ashes from soma British power stations and properties of their component particles. J Appl Chem, London, UK. 15(12): 595-604.

WCA. 2020. Coal \& Electricity. World Coal Association. Available online: https://www.worldcoal.org/coal/ uses-coal/coal-electricity.

WOSZUK A, BANDURA L \& FRANUS W. 2019. Fly ash as low cost and environmentally friendly filler and its effect on the properties of mix asphalt. J Clean Prod 235: 493-502. https://doi.org/10.1016/j.jclepro.2019.06.353.

XIE R, XU Y, HUANG M, ZHU H \& CHU F. 2016 Assessment of municipal solid waste incineration bottom ash as a potential road material. RMPD 18(4). https://doi.org/10. 1080/14680629.2016.1206483.

ZULKATI A, DIEW WY \& DELAI DS. 2012. Effects of Fillers on Properties ofAsphalt-Concrete Mixture. J Transp Eng138(7). https://doi.org/10.1061/(ASCE)TE.1943-5436.0000395. 


\section{How to cite}

BARRA B, MOMM L, GUERRERO Y, MIKOWSKI A, CLARA E, NGUYEN M-L \& HUGHES GB. 2021. Evaluation of Technical Feasibility of Reusing Coal Ash in Dense Asphalt Mixes by Assessing Mechanical Performance. An Acad Bras Cienc 93: e20201662. DOI 10.1590/0001-3765202120201662.

Manuscript received on October 18, 2020;

accepted for publication on August 25, 2021

\section{BRENO BARRA ${ }^{1}$}

https://orcid.org/0000-0003-2212-8163

\section{LETO MOMM ${ }^{1}$}

https://orcid.org/0000-0003-0243-7903

\section{YADER GUERRERO 1}

https://orcid.org/0000-0002-4048-050X

\section{ALEXANDRE MIKOWSKI ${ }^{1}$}

https://orcid.org/0000-0002-5348-8420

\section{ESTÉFANI CLARA}

https://orcid.org/0000-0001-7103-293X

MAI-LAN NGUYEN ${ }^{2}$

https://orcid.org/0000-0001-8966-5209

\section{GARY B. HUGHES ${ }^{3}$}

https://orcid.org/0000-0003-4739-8493
${ }^{1}$ Universidade Federal de Santa Catarina (UFSC), Departamento de Engenharias da Mobilidade (EMB), Rua Dona Francisca, 8300, 89219-600 Joinville, SC, Brazil

${ }^{2}$ Université Gustave Eiffel (former IFSTTAR), Route de la Bouaye, 44340 Bouguenais, France

${ }^{3}$ University of California, Santa Barbara (UCSB),

Department of Physics, Assistant Project

Scientist, Santa Barbara, CA 93106, USA

Correspondence to: Breno Salgado Barra

E-mail:brenobarra@gmail.com,breno.barra@ufsc.br

\section{Author contributions}

Breno Salgado Barra: Conceptualization, Writing - original draft, Data curation, Writing - review \& editing, Laboratory tests. Leto Momm and Yader Guerrero: Data curation, Writing - review \& editing. Alexandre Mikowski and Mai-Lan Nguyen: Conceptualization. Estéfani Clara: Laboratory tests. Gary B. Hughes: Writing - review \& editing.

\section{(cc) BY}

